\title{
The Dawn of Digital India- Television to Internet
}

\author{
Mrinal Singh \\ Amity School of Communication, NOIDA
}

\begin{abstract}
Television in India has developed into a phenomenon over the past decades. Its entry in India to its success is a subject widely discussed and under controversy from its beginning, till date. What is important and of utmost importance is, to understand its current picture and social understanding. Television, by definition, is a system for transmitting visual images and sound that are reproduced on screens chiefly used to broadcast programs for entertainment, information, and education. Since the beginning of broadcast media in India the focus has been information, education, awareness and entertainment. Tracing back the journalistic and entertainment forums in India to Indian freedom struggle one needs to focus on the sluggish growth due to various political and financial drawbacks. With everyday development in this technological era, we cannot risk to lag behind. The need to keep ourselves updated with all that goes around the world is growing like a well fertilized crop field. Hence the growth and shift of televised shows/ serials to internet is the one that one needs to understand and know what has led to this shift. Internet like television is still a developing phenomenon. Its expanse and reach, growing each second, cannot be overlooked. This paper aims to discuss this transition of one digital forum to another along with the inevitable reference to the ongoing globalisation.
\end{abstract}

Keywords: Digital, Television, Internet, India, Globalisation

\section{INTRODUCTION}

Television in India has developed into a phenomenon over the past decades. Its entry in India to its success is a subject widely discussed and under controversy since its beginning. What is important and of utmost importance is, to understand its current picture and social understanding. Television by definition is a system for transmitting visual images and sound that are reproduced on screens, chiefly used to broadcast programs for entertainment, information, and education. Since the beginning of broadcast media in India the focus has been information, education, awareness and entertainment. Tracing back the journalistic and entertainment forums in India to Indian freedom struggle one needs to focus on the sluggish growth due to various political and financial drawbacks. "Television was introduced in India on September 15, 1959 in Delhi, little over two decades after British Broadcasting Corporation (BBC) began the first television service of the world in 1936. It was with the help provided by UNESCO that it all started. The programmes were broadcast twice a week for an hour a day on such topics as community health, citizens' duties and rights, and traffic and road sense. In 1961 the broadcasts were expanded to include a school educational television project. The first major expansion of television in India began in 1972, when a second television station was opened in Bombay. This was followed by stations in Srinagar and Amritsar (1973), and Calcutta, Madras and Lucknow in 1975.

For the first 17 years, broadcasting of television spread haltingly and transmission was in black and white. By 1976, the network consisted of eight television stations covering a population of 45 million spread over 75,000 square kilometres. Faced with the difficulty of administering such an extensive television system as part of All India Radio, the government constituted Doordarshan, the national television network, as a separate Department under the Ministry of Information and Broadcasting." Dr. Mrinal Chatterjee This one paragraph from Media Magazine, published in September 2012 gives all that one needs to know about entry of television in the Indian scene and its initial growth. Knowing our history and facts about is one aspect of trying to understand the face of television today. Its growing transition towards internet and internet's popularity in urban Indians is makes us think 'is Television slipping into the same fate as radio and newspapers?' Though Radio and newspapers are still one of the very popular mediums of mass communication their future has been under speculation since the entry of visual media. So with the entry of Internet in the televised world and the desperate need to keep updated with changing times we are bound to ask this question. Why this change? What will be the result of this transition? Is our dear little idiot box running the risk of extinction?

\section{ROLE OF TELEVISION IN MAKING INDIA A DIGITAL PLATFORM}

Television came to India as a luxury. Being a new free country and struggling to make basic need fulfilment television was not embraced with open arms. This does not demean its importance. Two major facts effected the growth of television in India- Finance and Politics. 
Mass media originated with the idea of development, information and awareness. Be it print or any other form of newspapers, leaflets or brochures. The initial idea and the core focus even today is to provide information, promote development and create awareness. So, as Radio and Television are introduced to the world (even though decades apart) they bring about a revolution that the world had never seen before. After the discussions of NWICO (New World Information and Communication Order) there has been more focus laid on imparting information, technological advancement and great deal of emphasis on creating awareness about all the above.

Focusing on India as the 'third world country', as it was labelled at the time of independence; such factors did not pull India back. The drive to rise from the ashes left behind by the Britishers was strong. The leaders of the country pushed India to cope with economical, financial and political crisis. As Radio developed as the sole broadcasting medium it started to provide information to the masses faster and at a larger scale. This happened due to two main reasons- one, with newspaper, (the mass media medium before electronic media came into existence) comes a drawback at that time, literacy. Reading involves the knowledge and ability to read, write and speak of letters, words and sentences. Not many were literate enough to be able to read and/or write. Two, Radio basically works only on one sense of our body that is hearing. It, hence, developed to become one of the fastest and widely used medium of mass media. As radio is introduced, the drawback or lack of literacy within the country was immediately of no consequence when it came to providing information and creating awareness. As new technologies are invented, India grows along with it. As television is introduced in India it does not make the expected impact, contrary to what was forecasted by the Chanda Committee in 1966.

As expected and forecasted by Chanda Committee, television in India should have become a household element by mid 70s. On the contrary, due to the lack of financial implementations along with the ongoing political change within the country, the expectations were not met. Some of the remarks and proposals made in the Chanda Committee report were:

1. Look into the working of various media units in the information and broadcasting ministry.

2. Indian context is not possible for a creative medium like broadcasting to flourish under a regime of departmental rules and regulations.

3. An institutional change is needed to liberate the present rigid financial administrative procedures of the government.

4. For efficiency and economy the committee stressed the need for decentralization.

5. The committee recommended a corporate financial accounting system for AIR, its recruitment and financial activity.

6. The corporation must be set up only by an act of parliament.

7. It recommended the separation of television from radio and requested the formation of an independent television corporation.

Chanda committee focused on the current issues at hand and proposed to make changes that would make Television the new and powerful media source. Though this report pointed out the financial requirement for the setting up of such a huge market, it failed to forecast the problems that the newly free nation would face and hence it took almost 3 decades before television could become the media source it was expected to be. In this process various other committees such as the Verghese committee (1978), Joshi Committee (1985) and the Sengupta Committee (1990) also came in at times when more importance and the power of 'mass media' started becoming evident. In this procession of committees, came the Prasar Bharati Act in 1990 and Cable Television Act in 1995 to regulate and control the broadcasting methods and the content that would be allowed to be broadcasted. By 1990 television in India had become an important part of the system. As news bulletins, educational, developmental and entertainment shows came into focus, demand for television sets increased enormously. This now happens for various reasons. People (potential consumers) now have financial income that enabled them to afford television sets and services. The government, 33 years post independence, now allowed received cable television which gave people the option to receive all required information and entertainment just at a click of a button. The delay in the development of television as media king was also due to the political inconsistency within the country. The initial zeal and zest the government allowed experiments to be conducted and create a need for television but due to ongoing political hand change over 3 decades, till 1990s, made it difficult for any one proposal to get fulfilled. As we approach the 90s and enter it, television industry embraces the change it was expecting since its introduction in India. With the novella concept being introduced, shows like Ramayana and Mahabharata gave India the viewership that set the landmark for what could be expected of television in India. From community watching of these legendary shows we have moved to 'private' viewership on laptops and mobile phones. Another aspect to be kept in mind while analysing this change is the distinctively improved and new versions of the same epics today along with shows of the globalized world. Television has undergone significant technological and cultural change/development. 
The introduction of Cable television in India and regulating it over the years helped tin increasing television viewership by magnitudes. The stage that we are in today, the digitalized world, everything available to us, not talking about the HD televisions but the mobile TV and access to our 'personal televisions' is a matter of discussion everywhere. To discuss this enormous media leap we need to understand the importance of the growing globalization and what comes with it.

\section{SHIFTING TIMES}

"Internet Television is the quintessential digital convergence medium, putting together television, telecommunications, the internet, computer applications, games and more. It is part of a historic move from individualized narrowband... to one of broadband capacity..." The combination of Internet and television has helped the world come closer, intellectually and culturally. The delayed rise of television and rapid growth of internet (especially in urban areas) shows how India as coped with the 'sluggish growth' that was in the initial years of broadcasting.

The final years of the $20^{\text {th }}$ century saw drastic change and development in visual media development. Not only in terms of what was broadcasted in the cultural space but also the vast reach of these shows has increased viewership, crossing national boundaries and making almost all broadcasting material available to the masses. Crossing of the thinly veiled boundaries of broadcasting (television and radio) and internet has made people rethink the predicted development of Television. Over the past one decade, the small transition of news flashes on internet to every television channel, newspaper, radio channel, 'private' blogging spaces (part of social activism), they all now own their websites that are not only available free of cost (apart from the regular internet bill) but also providing live and current updates on the move.

People today have a disposable income. The struggle that even the elite faced at the time of introduction of television in India is no more holding the media development of the country. The parties in power also realise the power, influence and importance that all of media has on the masses and hence gets support from this front as well. The two major drawbacks that the country faced in its initial years have now been overcome. Of course there is still a disparity between the rich and the poor but that disparity is not at the level of accessibility but on the earning potentials. "India did not lag behind in the introduction of the new information technologies though, to begin with, the progress was tardy, and largely restricted to the elites in urban area, and to teachers and researchers in national science and research institutes." As internet started to creep in to the Indian society slowly but steadily, the desperate need to keep up with the globalized world increased. We wanted to match our steps with the world. Keep up with what was happening around the globe and be a participant not just a sideline audience.

The gap between the rich and the poor about the reach of this information technology across has been controversial. "There is indeed a yawning gap between the information-rich and the information -poor, and this gap is growing, since the costs of access are no where getting any easier or cheaper. The 'digital divide' is a grim reality both in the developed and the developing economies of the world." This debate of who gets more access and who uses it is clear cut. What we need and should focus on at the moment is the fact that we are keeping up with getting access and availing the world technologies. Instead of waiting for the country to cope with struggling factors such as to even have access to new and upcoming technologies.

\section{PLUS FACTORS}

The history, development and success of India's communication and mass media development is a never ending tale. What takes the centre-stage is how the country overcame the rumbles left behind by the British Rule. The rise is not in only communication and mass media sector but also in employment sector. "Telecommunications and information technologies were developed in advanced industrialised societies to serve their needs and interests. These societies needed capital intensive and labour saving technologies to make up for high labour costs and low populations. The 'new' technologies brought about speed, efficiency and a nonpolluting environment." The entry of various social media sites and world becoming a smaller place with reference to accessibility in terms of being able to be in touch with people across international waters and access to international product only a click away the employment horizons have magnified drastically. Introduction of You Tube and open and free access to interact with its reach to millions of population with such an ease only aggravated the already rapid mass communication development. Shows like TVF- Pitchers, TVF- Permanent Roommates, YFilms-Band, Baja, Baraat, AIB podcasts, Being Indian, Happy to be single and many other have changed the entire 'idiot box' scenario. What we were only watching on television- shows, news, new music release, etc all is available at our own convenience in brilliant quality on our personal systems be it a laptop or a mobile phone. Apart from this J Kumar also points out in his book "that since the 1980s, when economic liberation was introduced in India, female employment has increased. The female work participation rate...has increased to $9.74 \%$ in 1991 from $8.3 \%$ in 1981 ." The benefits of development of mass communication cannot be overlooked, not only has the developing media sources increased the need and demand to be aware of our 
surroundings; it has also increased awareness regarding various other basic necessities. We today have women leading media houses and running news stories. The employment rates (as indicated by J Kumar) have increased drastically over the years.

Since then (1950s- 1980s, the sluggish era), the modes (film, television, Internet, Print or Radio) of communication have increased and the outlets too (newspapers, magazines, Radio sets, Television sets, mobile phones, computer sets or laptops) Both- mode and outlet, are inter-related. The availability of resources has increased as the government realises the importance and need for the development of the country. We need to keep up with the pace that the world is growing. Now that the political and financial standing of the country is more firm, we move ahead hand in hand with the ever shrinking global world. We live in a world where news reaches us faster via applications available on our mobile phones, which is almost making television and its function redundant. But is it so? Will Television slide into oblivion in the super fast age of Internet and Technology? This was the same question raised when we moved from Print to Radio and then Radio to Television. The answer, only time and world requirement will tell. We have had significant development in the technical field of television as well which has only led to faster and higher development in Internet productions and viewership.

The development of Indian television though sluggish initially, has been tremendous in the past. Internet poses a threat but not as much as it has complemented television's development. Television has become an Idea as it moves away from the mere concept of the 'idiot box'. We still watch 'television' on our laptops and mobile phones. Internet has taken television to new heights of accessibility. They both complement each other. Right now, the two are battling a fight of who remains the favourite.

\section{Web Sites}

\section{BIBLIOGRAPHY}

[1]. Media Magazine (2012) , Dr. Mrinal Chatterjee, 53 Years of Indian Television. (accessed on June 2016)

[2]. Press Information Bureau, Prasar Bharati: An Appraisal, Raghunath Raina, Media Critic. (Accessed on June 2016)

\section{Books}

[3]. Gupta, V.S., (1995), Third Revolution in Indian Perspective: Contemporary Issues and themes in Communication, New Delhi : Concept Publishing Company.

[4]. Mathur, Kanwar B, (2005), Fundamentals of Communication Policy for India: The emerging cyber democracy, Allied Publishers.

[5]. Noam, Eli; Groebel, Jo; Gerbarg, Darcy. (2004), Internet Television, Lawrence Erlbaum Associates.

[6]. Aggarwal, Vir Bala : Gupta, V. S. (2002), Handbook of Journalism, New Delhi: Concept Publishing Company.

[7]. Kumar, Keval J. (2010), Mass Communication in India, Jaico Publishing House. 